\title{
Evaluating legal literacy programmes - aims, challenges, models and a call to action
}

\author{
Richard Grimes ${ }^{1}$
}

\section{Building 'best practice' ${ }^{2}$}

Generally speaking, if one asks most people whether improving public understanding of the law and legal system is a good thing, most hands will go up. This is perhaps no surprise. An improved level of legal literacy should not only raise awareness of rights and responsibilities but may well provide people with more of an informed choice about what to do if they encounter legal issues. It might give those concerned the tools and confidence to address some of these problems themselves through self-help and it may, address, at least to some degree, inequalities that otherwise exist. Overall, improving levels of legal literacy could enhance access to justice more generally. The generic term often ascribed to raising legal awareness amongst the wider population is public legal education (PLE).

\footnotetext{
${ }^{1}$ Formerly Director of Clinical Programmes, York Law School, University of York, UK and now a legal education and access to justice consultant, and contactable at: richard.grimes@hotmail.co.uk

${ }^{2}$ This contribution is based on a presentation and discussion that took place at the Ed O'Brien memorial workshop on Street Law best practice in Durban, South Africa in April 2016. I am grateful for all who attended that session and for their insights. Thanks must also go to David McQuoid-Mason and the other staff at the School of Law, KwaZulu Natal University and the South African Street Law movement more generally for their vision, organisation and commitment in setting up the event and in following through with the publication of which this is a part. 'Best practice' is used here in the sense of not what is best per se but rather what models, techniques and approaches can be devised, adapted and implemented through proven work elsewhere.
} 
There is a wealth of anecdotal material suggesting that all of the above is highly relevant and impactful ${ }^{3}$ but there is little by way of clear empirical evidence to substantiate such claims. ${ }^{4}$

This article will look at the need for, and means of, developing such an evidence base and ends with a plea for more research, sharing of ideas and collaboration in terms of evaluating PLE. The article will be presented in the format of an introductory section looking at the background and history of PLE (in particular Street Law) in terms of aims, challenges and models from the perspective of evaluating impact.

This is followed by a 'lesson plan' in which a sample set of possible PLE options are set out with the means of evaluating impact incorporated in the model used. It is hoped that this might provide a guide for those wishing to devise (or revise) their legal literacy programmes from an evaluative viewpoint.

As will be seen below the starting point is that those responsible for design and delivery must identify what it is they are expecting to achieve from any planned session and whether those outcomes are in fact reached. This type of evaluation, formative evaluation, measures whether the objectives of any particular lesson are

\footnotetext{
${ }^{3}$ There is a great deal of published work on the perceived benefits of PLE - see for example: the collection of articles in J. Robins (Ed.), Waking up to PLE : Public legal education, access to justice \& closing the justice gap, Justice Gap series, Solicitors' Journal, 2013 and, more jurisdictionally and community-specific: J. Krishnan, S. Kavadi, A. Girach, D. Khupkar, K. Kokal, S. Mazumdar, Nupur, G. Panday, A. Sen, A. Sodhi, and B. Shukla, Grappling at the Grassroots: Access to Justice in India's Lower Tier, Harvard Human Rights Journal, Vol. 27, 2014, 151.

${ }^{4} \mathrm{~A}$ recently published study in the USA does however highlight the impact of one prominent PLE approach Street Law - on school pupils although even this study highlights the need for further research. See: Sean G. Arthurs, Street Law: Creating tomorrow's citizens today, Lewis and Clark Law Review, 19:4, 925.
} 
achieved and provides sign posts for how to revise instruction to ensure objectives are achieved.

The template should enable those using it to replicate and, as necessary, adapt an evaluable model for use in the field.

This paper then has a sample form appended as an example of how PLE sessions might be evaluated.

\section{Aims}

Before turning to the models and impact measurement what specifically are the purposes of evaluation? Evaluation is important for several related reasons. First and foremost if planned outcomes and actual achievements are not clear how can the value of what is being carried out be assessed - with a view to monitoring progress, awarding possible credit and making improvements in future delivery? More strategically perhaps, and as will be seen, many PLE initiatives rely on either public funding, the backing of foundations and other charitable bodies and/or the input of voluntary and not for profit personnel and initiatives. The relative lack of impact evidence is surely an obstacle to securing financial and other resource backing? The aim therefore of this article is to raise the importance of evaluation and to identify the means by which any assessment may be carried out.

In a nutshell, can we identify:

- whether outcomes set for a particular PLE session or event have been achieved? 
- if future planning and delivery can be improved?

- whether there is impact - what difference does an improvement in legal awareness actually make in the immediate, short-term or longer-term contexts?

- if and how the evidence can be used for development purposes - for example funding, curriculum design, policy change?

- if findings of an empirical nature match what instinct and anecdote suggests thus building a body of evidence that has consistency and resonance. ${ }^{5}$

\section{Challenges}

First, what is meant here by PLE? At its most general, it is the raising of awareness of law and the legal system through a variety of techniques and methods including the provision of information (hard copy, electronic and face to face) as well as through a more formal education interface such as one-off presentations or structured courses and programmes. This takes into account the Street Law approach where target audiences are introduced to a range of legal rights and responsibility issues through interactive learning and teaching techniques often lead by lawyers, judges, and trained law students under professional supervision. ${ }^{6}$

\footnotetext{
${ }^{5}$ For example the claims made by the Bethel Institute through their learning pyramid - as discussed in A. Kumar, Personal, Academic and Career Development in Higher Education - SOARing to Success, Routledge Taylor \& Francis, 2007

${ }^{6}$ Some Street Law programmes are delivered by in-house teams largely based in NGOs, the initiators and probably the most prolific in the USA and internationally being Street Law Inc., Washington DC. Others are lawschool based. For a discussion on the history and current prevalence of Street law programmes see: R. Grimes, E. O'Brien, D. McQuoid-Mason and J. Zimmer, Street Law and Social Justice Education, in The Global Clinical Movement: Educating Lawyers for Social Justice, F. Bloch (ed.), OUP, 2010. I do not suggest here that students
} 
There seems to be a degree of consensus that PLE should include, but not be limited to, the dissemination of information. A point often made is that in addition to the acquisition of knowledge, PLE involves fostering understanding and the development of skills. It is also argued that PLE should aim to influence attitudes, and build confidence. Distinctions need to be drawn between information per se and education more generally. The latter commonly involves custom made and subject specific material, delivered more than likely in an interactive way, whereas the content of the former tends to be generic, with the direction of flow largely being one way, from 'expert' to recipient. It also is inclined to treat the audience as a passive receiver of that information. Street Law is probably the best example of the education model and one that shapes part of the evaluation template examples given below.

The quest for robust evaluative evidence is, however problematic. This is on a number of levels. First, what is being measured and secondly, how might that measurement be reliably and consistently done? It should also be remembered that studies involving sensitive data may need ethics approval from professional or other institutional bodies (such as universities whose staff or students carry out research) and that there may be legislative requirements over the handling of such data.

One way to measure social impact is to study widespread changes over time. However, the literature suggests that neither the measures nor the tools appear to exist

are or necessarily make, good teachers, but their use in many PLE programmes is a model that can have multiple beneficiaries including the students themselves. 
in the PLE context (although there have been a number of evaluative studies in other disciplines using defined methodologies). ${ }^{7}$

In UK Ministry-led task force on PLE in 2007, PLE presented the following challenges that affect both planning and evaluation:

- $\quad$ PLE sessions or materials are typically part of some larger curricula

- $\quad$ PLE is unlikely to be clearly recognised by practitioners

- $\quad$ PLE is frequently tailored to achieving goals for users

- $\quad$ target 'audiences' for PLE initiatives vary widely by age, background, ability and needs

- $\quad$ participants in PLE-related work are unlikely to recognise its nature or scope

- the goals of PLE may focus on different outcomes including changes in behaviours, skills and attitudes. ${ }^{8}$

In addition, the lack of a 'like with like' comparison and the nature of learning as process rather than product make evaluation challenging to say the least. ${ }^{9}$ By way of

\footnotetext{
${ }^{7}$ For example see: C. Brennan and K. Gallagher, Consumer Support Networks: improving consumer advice in the UK, International Journal of Consumer Studies, 26 (3), 227, 2002; and Financial Services Authority, Measuring financial capability: an exploratory study, FSA, 2005

8 PLEAS Task Force, Developing capable citizens: the role of public legal education, Department for Constitutional Affairs, Russell Press, 2007

${ }^{9}$ For the product vs. process debate see: S.J. Lachman, Learning is a process: toward an improved definition of learning, The Journal of Psychology: interdisciplinary and applied, 131 (5), 1997, 477
} 
contrast few ask for the learning legitimacy of other forms of education to be proven. Judging by the number of students reportedly disinterested in lectures, a similar study on impact and the value-added component of learning passively might be usefully called for! ${ }^{10}$

All of these factors or characteristics have measurable dimensions and may be interrelated. The measurement of impact is therefore complex and difficult.

Measuring how and when improved awareness rises to the level of impacting a participant's ability to implement the newly acquired knowledge or skill is also difficult to establish - particularly in trying to identify cause and effect. This has previously been shown to be the case in legal self-help situations. ${ }^{11}$

Despite these challenges, it is suggested here that impact can be measured at different moments in time and with different techniques and approaches. A combination of methods and, where relevant, an amalgamation of findings coupled with subsequent analysis can reveal valuable insights on impact and outcomes. Let us turn to this now.

\footnotetext{
${ }^{10}$ The evidence for this is largely anecdotal but supported by much of the literature on learning and teaching. See for example; G. Gibbs Twenty terrible reasons for lecturing, SCED Occasional Paper No. 8, Birmingham. 1981.

${ }^{11}$ See: J. Giddings, M. Lawler and M. Robertson, The Complexities of Legal Self-Help, in: J. Robins, op cit, 50
} 


\section{Models}

Space in this article does not permit a detailed discussion of evaluative research techniques. For those interested there is a wealth of material available elsewhere. ${ }^{12}$

Suffice it to say for present purposes that useful evaluation might consist of a mix of quantitative and qualitative methods. These might start with a simple record of the number of those attending PLE sessions or accessing PLE material. Entry and exit questionnaires might be used to see what the target audience expected and then made of the materials and/or presentations. If a particular PLE project is targeted at a specific issue it may be possible to monitor impact in terms of the resolution of disputes, take up of benefits or incidence of unwarranted activity such as domestic violence, unlawful eviction or anti-social behaviour (in each instance in terms of both number and participant perception). Focus groups could be used to prompt feedback and discussion. Evidence could be gathered from PLE participants (the audience, the

\footnotetext{
${ }^{12}$ See for example: S. Halliday and P. Schmidt, (Eds.). Conducting Law and Society Research: Reflections on Methods and Practices, Cambridge University Press, 2009. There are also important studies in other subject fields that attempt to evaluate impact - for example in youth justice, numeracy and financial literacy and in consumer protection - see: J. Kenrick, Young People's Social Welfare Need and the Impact of Good Advice, Youth Access, 2007; Financial Services Authority, Towards a National Strategy for Financial Capability, Financial Services Authority, 2003, Financial Services Authority, Measuring Financial Capability: an Exploratory Study, Financial Services Authority, 2005 and Financial Services Authority, Levels of Financial Capability in the UK: Results of a Baseline Survey, Financial Services Authority, 2006; and, Individuals' awareness, knowledge and exercise of employment rights, 2007 and the annual Competition Act and Consumer Rights survey Office of Fair Trading (UK), respectively. Citizenship education more generally was the subject of a longitudinal study in the UK, which began in 2001 and ran until 2009. The report on the findings can be found in: A. Keating, D. Kerr, T. Benton, E. Mundy and J. Lopes, Citizenship education in England 2001-2010: young people's practices and prospects for the future: the eighth and final report from the Citizenship Education Longitudinal Study, National Foundation for Educational Research, DFE, 2010.For an interesting account of PLE programmes and evaluative methods see: M. Sefton, Public Legal Education Strategy (PLES) Task Force Scoping Report, Paper 2/03a, Research Unit, Department for Constitutional Affair, 2006 (from which the citations to some of the reports referred to in this footnote were taken).
} 
presenters and other stakeholders) before, at, after and following the event of release of material in question. The appendix to this paper contains an example of how session delivery might be evaluated. Of course any evaluation will hinge on what is expected and that might vary considerably, for example if a PLE session was a one-off event looking at a particular issue or was more overtly educational in an incremental sense such as a short course or semester-long module.

Hard evidence may be relatively easily obtained when impact can be measured at the time of or soon after the PLE input. The much more difficult question as to lasting or longer-term significance of an increase in legal awareness inevitably requires longitudinal studies which are, by their nature, time-consuming to carry out, relatively expensive to administer and difficult to firmly establish cause and effect. Some notable examples of highly successful studies in the legal awareness field (rather than impact of PLE as such) can be found and make for interesting reading. ${ }^{13}$ The Pleasance et al Causes of Action studies, based on a rolling programme, for instance show the very high price paid for unresolved legal disputes (some GBP $£ 3.5$ million a year and not including the human cost). It begs the question of the extent to which a greater awareness of legal rights and responsibilities might mitigate against such waste and the negative impact on personal well-being.

\footnotetext{
${ }^{13}$ For example: H. Genn, Paths to Justice: What People Do and Think About Going to Law Hart, 1999 and P. Pleasance, N. Balmer, A. Patel, A. Cleary, T. Huskinson and T. Cotton, Civil Justice in England and Wales: Report of Wave 1 of the England and Wales Social and Civil Justice Panel Survey Legal Services Commission and Ipsos Mori, 2011
} 


\section{A suggested template and examples of evaluation in a Street Law context}

Let us therefore take the issues and principles identified above and put theory into practice by designing lesson plans that address the need for evaluation.

In order to stress the importance of a clear structure for PLE preparation and delivery and to act as a guide for those developing PLE programmes a common template is used throughout this book. This uses the following format:

Who is the PLE directed towards - audience?

What is covered - topic/subject matter?

What is the purpose - learning outcomes?

Where and when will it happen - location and day/time?

Who is doing what - preparers, presenters and any relevant supervision?

Content - what knowledge, skills and/or values are to be covered?

How will it be done - mode of delivery with timings (focuser, small groups, report back, wind up and evaluation)?

What is needed - resources (materials, equipment, room(s) and people)?

How was it - for you and them?

What next - future progress? 
For illustrative purposes we will work with two examples here following a similar template; first, there is a plan for delivery of a typical Street Law session and secondly a plan for the use of hard copy legal information (which could also/instead be delivered as part of a web-based PLE project).

Example 1 - work plan for a 'typical' Street Law session on stop and search provisions under domestic law ${ }^{14}$

Institution: a law school running a credit bearing module called 'Law in the community'

\begin{tabular}{|c|c|c|c|}
\hline Item & Details & Timings & Comments \\
\hline Target audience & $\begin{array}{l}\text { Young people in a 'special' } \\
\text { school for pupils with a } \\
\text { record of prior poor school } \\
\text { attendance. }\end{array}$ & & $\begin{array}{l}\text { Check age and } \\
\text { capacity of } \\
\text { pupils. Do risk } \\
\text { assessment. }\end{array}$ \\
\hline Topic & $\begin{array}{l}\text { Police stop and search - your } \\
\text { rights and responsibilities. }\end{array}$ & & $\begin{array}{l}\text { Teachers at } \\
\text { school have said } \\
\text { that some pupils } \\
\text { are often subject } \\
\text { to stop and } \\
\text { search as they } \\
\text { have a } \\
\text { 'reputation' } \\
\text { amongst local } \\
\text { police. }\end{array}$ \\
\hline $\begin{array}{l}\text { Learning outcomes } \\
\text { (LOs) }\end{array}$ & $\begin{aligned} \text { For pupils: } & \\
\text { 1. } & \text { To be able to } \\
& \text { specify when a } \\
& \text { police officer can } \\
& \text { insist that a } \\
& \text { person stops and }\end{aligned}$ & & $\begin{array}{l}\text { The learning } \\
\text { outcomes must } \\
\text { be SMART }{ }^{16} \text { and } \\
\text { for evaluation } \\
\text { purposes need to } \\
\text { be linked to the }\end{array}$ \\
\hline
\end{tabular}

\footnotetext{
${ }^{14}$ This example was provided by delegates at the Ed O'Brien Street Law conference, Durban, South Africa, April 2016

${ }^{16}$ Specific, Measurable, Appropriate or Assignable, Relevant or Realistic and Timely or Time-bound - see: G. Doran, There's a S.M.A.R.T. way to write management's goals and objectives, Management Review (AMA Forum) 70(11), 35, 1981.
} 


\begin{tabular}{|c|c|c|c|}
\hline &  & & $\begin{array}{l}\text { assessment } \\
\text { methods. }\end{array}$ \\
\hline Location/day/time & $\begin{array}{l}\text { The stop and search lesson is } \\
\text { one of a series of 'know your } \\
\text { rights' presentations to be } \\
\text { delivered at the school on a } \\
\text { set day per week for one } \\
\text { hour. }\end{array}$ & $\begin{array}{l}60 \text { minutes plus } \\
\text { travel time. }\end{array}$ & $\begin{array}{l}\text { Timings will need } \\
\text { to be agreed with } \\
\text { the school staff } \\
\text { and normally fit } \\
\text { into an allotted } \\
\text { timetable space. }\end{array}$ \\
\hline $\begin{array}{l}\text { Preparation/delivery/ } \\
\text { supervision (who?) }\end{array}$ & $\begin{array}{l}\text { A team of } 5 \text { law students will } \\
\text { research the law and } \\
\text { applicable procedures and } \\
\text { will deliver the session at the } \\
\text { school. One staff member to } \\
\text { supervise preparation and } \\
\text { delivery. }\end{array}$ & & $\begin{array}{l}\text { The content and } \\
\text { delivery format } \\
\text { will be checked } \\
\text { by the supervisor } \\
\text { (an ex-practising } \\
\text { lawyer in the law } \\
\text { school). }\end{array}$ \\
\hline Content & $\begin{array}{l}\text { 1. Police powers to stop } \\
\text { an individual/group } \\
\text { 2. Police powers to } \\
\text { consequently search } \\
\text { persons/property } \\
\text { 3. Consequences of } \\
\text { refusing to stop or be } \\
\text { searched } \\
\text { 4. Possible sources of } \\
\text { help if arrested } \\
\text { 5. Possible action/ route } \\
\text { for complaint if police } \\
\text { powers exceeded or } \\
\text { person otherwise }\end{array}$ & & \\
\hline
\end{tabular}

\footnotetext{
${ }^{15} \mathrm{~A}$ separate set out learning outcomes are required if the law students are expected to achieve certain educational goals. These will vary according to the module studied and the level at which it is offered e.g. first year or final year of study. For reasons of space limitation these details are not included in the template here.
} 


\begin{tabular}{|c|c|c|c|}
\hline & $\begin{array}{l}\text { unhappy with } \\
\text { treatment exceeded. }\end{array}$ & & \\
\hline $\begin{array}{l}\text { Delivery (how, logistics } \\
\text { and timings) }\end{array}$ & $\begin{array}{l}60 \text { minutes using interactive } \\
\text { techniques. }\end{array}$ &  & $\begin{array}{l}\text { Timings are } \\
\text { approximate and } \\
\text { flexible but need } \\
\text { to be monitored. } \\
\text { If the session is } \\
\text { likely to overrun } \\
\text { additional time } \\
\text { may be found in } \\
\text { a following } \\
\text { session. }\end{array}$ \\
\hline Resources & $\begin{array}{l}\text { Paper, pens, flip chart, props } \\
\text { for role play, room large } \\
\text { enough for role- } \\
\text { play/discussion, possibly a } \\
\text { prize and/or refreshments. }\end{array}$ & & \\
\hline $\begin{array}{l}\text { Outcomes (check if LOs } \\
\text { are achieved) }\end{array}$ & Quiz with prize(s). & & \\
\hline $\begin{array}{l}\text { Other evaluation } \\
\text { (target audience and/or } \\
\text { presenters) }\end{array}$ & $\begin{array}{l}\text { Questionnaire for students to } \\
\text { complete before and after the } \\
\text { event; follow up session }\end{array}$ & & \\
\hline
\end{tabular}

${ }^{17}$ A useful devise in which observers can stop then action during a role play if they think what is happening is incorrect or could be improved. The objector then assumes the role of the person who was interrupted. For a discussion of this technique see: http://dramaresource.com/forum-theatre/, accessed 1 June 2016. 


\begin{tabular}{|l|l|l|l|}
\hline & $\begin{array}{l}\text { recapping on subject matter } \\
\text { of this presentation; inclusion } \\
\text { of stop and search questions } \\
\text { in pupils' course assessment. }\end{array}$ & & \\
\hline $\begin{array}{l}\text { Review for further } \\
\text { development }\end{array}$ & $\begin{array}{l}\text { Discussion with school staff } \\
\text { on value of session; debrief } \\
\text { for law students post-event. }\end{array}$ & & \\
\hline $\begin{array}{l}\text { Link with future } \\
\text { projects/sessions }\end{array}$ & $\begin{array}{l}\text { Part of on-going set of } \\
\text { presentations. Development } \\
\text { of similar programmes at } \\
\text { other venues. }\end{array}$ & & \\
\hline
\end{tabular}

Example 2 - work plan for a tool kit on self-representation before courts and tribunals ${ }^{18}$

Institution responsible: Advocacy rights - an NGO supporting unrepresented litigants ${ }^{19}$

\begin{tabular}{|c|c|c|}
\hline Item & Plan & Comments \\
\hline Target audience & $\begin{array}{l}\text { Advocacy groups and their } \\
\text { members. }\end{array}$ & $\begin{array}{l}\text { Important to make } \\
\text { links with } \\
\text { local/regional/national } \\
\text { groups and any } \\
\text { relevant networks. }\end{array}$ \\
\hline Topic & $\begin{array}{l}\text { Representing yourself in civil } \\
\text { courts and tribunals. }\end{array}$ & \\
\hline Learning outcomes (LOs) & $\begin{array}{l}\text { For users: } \\
\text { 1. To know where the local } \\
\text { courts and tribunals are } \\
\text { located } \\
\text { 2. To know how to start or } \\
\text { respond to the issue of } \\
\text { legal proceedings } \\
\text { 3. To be able to recognise } \\
\text { what will happen next } \\
\text { once proceedings are } \\
\text { issued } \\
\text { 4. To be able to gather and } \\
\text { present relevant evidence } \\
\text { 5. To know how to address } \\
\text { the court or tribunal } \\
\text { 6. To know where to go to } \\
\text { for help if required. }\end{array}$ & $\begin{array}{l}\text { The purpose of the } \\
\text { toolkit is to provide an } \\
\text { overview of legal } \\
\text { proceedings so that a } \\
\text { non-lawyer can } \\
\text { recognise what } \\
\text { happens and why in } \\
\text { legal proceedings } \\
\text { before courts and } \\
\text { tribunals. }\end{array}$ \\
\hline
\end{tabular}

\footnotetext{
${ }^{18}$ This example is included to contrast with the more typical Street Law presentation

${ }^{19}$ This is a fictional NGO but based on various manifestations in the UK and other countries for example - the Rotherham Advocacy Partnerships. More information on this can be found at:

http://www.rotherhamadvocacy.org.uk/, accessed 1 June 2016.
} 


\begin{tabular}{|c|c|c|}
\hline Location/day/time & Not relevant & \\
\hline $\begin{array}{l}\text { Preparation/delivery/supervision } \\
\text { (who?) }\end{array}$ & & $\begin{array}{l}\text { The preparation will } \\
\text { be supervised by an } \\
\text { experienced practising } \\
\text { lawyer. }\end{array}$ \\
\hline Content & $\begin{array}{l}\text { 1. Overview of jurisdiction of } \\
\text { courts and tribunals } \\
\text { 2. Issue of proceedings } \\
\text { 3. Preliminary hearings and } \\
\text { orders } \\
\text { 4. Evidence } \\
\text { 5. Trial } \\
\text { 6. Remedies and other court } \\
\text { 7. Settling cases out of court } \\
\text { 8. Sources of help for } \\
\text { litigants in person. }\end{array}$ & \\
\hline $\begin{array}{l}\text { Delivery (how, logistics and } \\
\text { timings) }\end{array}$ & $\begin{array}{l}\text { Booklet available in hard copy or } \\
\text { in an e-version and available on } \\
\text { NGOs' websites. }\end{array}$ & \\
\hline Resources & $\begin{array}{l}\text { Distribution points in publically } \\
\text { accessible places (e.g. libraries and } \\
\text { schools). Links to websites. }\end{array}$ & \\
\hline $\begin{array}{l}\text { Outcomes (check if LOs are } \\
\text { achieved) }\end{array}$ & $\begin{array}{l}\text { A questionnaire to be } \\
\text { incorporated in the booklet/on } \\
\text { website. }\end{array}$ & \\
\hline $\begin{array}{l}\text { Other evaluation (target } \\
\text { audience and/or presenters) }\end{array}$ & $\begin{array}{l}\text { Focus groups of users and } \\
\text { court/tribunal staff. }\end{array}$ & \\
\hline Review for further development & $\begin{array}{l}\text { Informed by focus group. A } \\
\text { suggested template for user/other } \\
\text { stakeholder feedback is appended } \\
\text { to this article. Possible link with an } \\
\text { academic institution/government } \\
\text { department to conduct empirical } \\
\text { and longitudinal 'impact' study. }\end{array}$ & \\
\hline $\begin{array}{l}\text { Link with future } \\
\text { projects/sessions }\end{array}$ & $\begin{array}{l}\text { Future plans depend on nature of } \\
\text { feedback. }\end{array}$ & \\
\hline
\end{tabular}




\section{Summary of evaluation 'best practice'}

Potential roles for PLE include the raising of awareness of rights and responsibilities generally, preventing problems from arising or escalating and assisting (directly through improving self-help capacity or indirectly through enhancing the ability to identify a problem) and then recognising routes through which further assistance can be sought, such as referral to another agency (including a lawyer).

In any version in which PLE is targeted at individuals or groups with problems and issues, PLE might also focus on those who assist others - for example a training of trainers or development of para-legal model. ${ }^{20}$ In either case when working with the target audience evaluation is still critical in order to monitor the educational process as well as to allow for fine-tuning and other future development.

Whilst evaluation is problematic, particularly in terms of robust methodologies and the inevitably long-term nature of impact studies, a careful review of expected outcomes and utilisation of a range of research techniques may enable the impact of PLE to be monitored and analysed for the long-term benefit of wider community.

Clearly there is much work to be done on developing, funding and conducting PLE impact research. This brief paper is intended to help kick-start that process. If anyone is interested in working on PLE evaluation please contact the editors of this journal.

\footnotetext{
${ }^{20}$ See for example: P. Patel, Z. Douglas and K. Farley, Learning from a 'paralegals' intervention to support women's property rights in Uganda, international Centre for Research on Women, 2014, available at: http://www.icrw.org/sites/default/files/publications/ICRW\%20Uganda\%20Paralegals final.pdf, accessed 1 June 2016
} 
Appendix

Evaluation Template Form

Please complete the following set of questions in as much detail as possible for your PLE

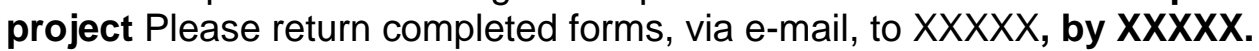

\begin{tabular}{|l|l|}
\hline Project Reference: & \\
\hline Project Title: & \\
\hline Lead Organisation: & \\
\hline Project Start Date: & \\
\hline
\end{tabular}

a. Please provide a brief summary of the aims of the project and state how these will be, or have been, achieved:

b. Which of the sub-themes does the project fall into? (please refer to guidance attached but please amend if these are incorrect and add the groupings by client and category.)

Client Group:

Category:

Project objective:

c. How has the project provided concrete and material help for targeted clients (this should be based on real examples and should include the number of clients helped and the level of help delivered)?

\section{Example(s)}

d. What have been the long-term impacts of the project, if any, and how has the project secured these improvements?

e. Are there aspects of the project that could be replicated elsewhere, if so, what are they and under what circumstances would it be appropriate to replicate these (this could include information materials that have been produced by the project, for example)?

f. What impact has any funding (including matched funding) had on the project? Has it added value to the project, is so, how 
g. What links, if any, has the project had or made to other initiatives (government/council/otherwise)?

h. What difficulties, if any, has the project experienced?

i. What plans are there for this or related projects in the future and what is required to achieve these? 